\title{
KONSTRUKSI MAKNA ISTILAH DALAM GARAP REBAB SUNDA
}

\author{
Caca Sopandi \\ Prodi Karawitan Fak. Seni Pertunjukan \\ Institut Seni Budaya Indonesia (ISBI) Bandung \\ Email: caca_sopandi@isbi.ac.id
}

\begin{abstract}
The terms applied in working on playing the rebab in Sunda certainly appear after the musical form. In fact, the terms also mostly use terms that are considered to be the closest to reality both audio and visual. However, there are a number of other terms which are based more on things outside of reality, so that the construction of the meaning of these terms contains messages far beyond the technique. The problems in this study are: (1) What are the meaning constructions that underlie the creation of terms in the Sundanese rebab work? (2) What is the correlation between the terms that are built with the form of Sundanese rebab musicality? The purpose of this study is to find out, understand and explain: (1) the construction of the meaning of terms in the Sundanese rebab, (2) the correlation of terms with their musicality. Data collection techniques used were participant observation, interview and documentation study. Data analysis is carried out by identifying, reducing, clarifying, describing, interpreting and concluding all information selectively. The results of the research show that: (1) the terms used in the rebab play are two categories of terms, including terms with denotative conceptual meanings, and terms with connotative meaning concepts, (2) The technique of playing the rebab requires accuracy, precision, and interpretation. Therefore these terms are used as methods and strategies in the process of inheritance.
\end{abstract}

Keywords: Construction, meaning, term, rebab, Sundanese.

\section{Pengantar}

Istilah yang biasa digunakan dalam garap rebab Sunda dalam perspektif bahasa sungguh mengandung makna yang mendalam. Kata yang digunakan berasal dari makna empirik yang biasa digunakan dalam kehidupan sehari-hari, yang kemudian menjadi bahasa simbol musik dalam teknik garap memainkan rebab Sunda. 
Simbol musik tersebut tidak sembarang menggunakan kata yang tak bermakna, namun telah mengalami seleksi alam yang sudah berlaku sejak lama. Simbol tersebut terpilih berdasarkan korelasi dengan berbagai hal, perilaku sosial, wujud benda, tindakan, organologi dan sebagainya. Satu jenis tindakan melakukan teknik garap rebab pada suatu daerah, belum tentu sama istilahnya di tempat lain, terutama setelah menjadi bagian perangkat kesenian yang berbeda.

Dalam kategori peran, seluruh waditra dalam sebuah ensemble gamelan sudah terikat dengan fungsinya masing-masing. Proses pembagian peran tersebut selalu didasarkan pada pembagian wilayah pekerjaan yang dibatasi ruang dan waktu. Berkenaan dengan fungsi itulah, maka dalam pengkategoriannya terdapat strukturalisasi, yang secara tidak langsung telah menciptakan hirarkinya sendiri.

Salah satu waditra yang diklasifikasikan memiliki tempat tertinggi dalam kategori peran dan fungsi, di antaranya adalah waditra rebab. Waditra rebab dalam seni karawitan Sunda, memiliki beberapa fungsi dan salah satu fungsi utama yang sangat melekat sampai saat ini, yaitu fungsinya sebagai lulugu lagu. Sekaitan dengan itu, Suryaman menyebutkan bahwa: seorang pemain rebab yang baik, bukan pemain yang hanya mampu secara individu mendemonstrasikan dengan menunjukan ornamentasi-ornamentasi atau senggol-senggol saja. Tapi justru peran utamanya sebagai lulugu, pamingpin atau penuntun sekar (wawancara, Bandung 2010)

Karena fungsi-fungsi itulah, maka waditra rebab telah dikonstruksi masyarakatnya sebagai salah satu instrumen yang termasuk sulit dipelajari, sehingga populasi pengrebab muda sangat lambat. Hal ini bisa dicermati secara teknis, sebab nada-nada yang dihasilkan sangat membutuhkan akurasi dan presisi dari pemainnya. Berbeda dengan waditra lain, seperti suling, kacapi, dan waditra-waditra lainnya yang notabene, nada-nadanya sudah pasti. Oleh sebab itu tidak heran seandainya populasi pemain rebab Sunda sangat terbatas dibanding dengan kompetensi lainnya dalam bidang seni karawitan Sunda. Karena kesadaran itu pula maka sejak dulu berbagai upaya telah ditempuh oleh beberapa seniman kreatif, dengan memunculkan strategi-strategi, yang salah satunya menciptakan istilah- 
istilah berupa kata-kata bermakna sebagai metode yang kemudian digunakan dalam proses pewarisannya, sebagai bentuk kepedulian terhadap kelangsungan regenerasinya, seperti disebutkan Sumarjo (2000:85) dalam tulisannya, bahwa: "setiap seniman yang kreatif adalah seniman yang peka dan tanggap terhadap lingkungan hidupnya, baik tradisi budayanya maupun kenyataan faktual lingkungannya."

Dari beberapa istilah berupa kata dalam waditra rebab, secara teknis bisa dikuasai melalui interpretasi dari pemainnya, karena lebih mencerminkan kesan musikalitas bersifat kontemplatif, sehingga istilah-istilah tersebut merupakan kontemplasi dari teknik memainkannya. Hal tersebut juga sangat umum diterapkan dalam waditra-waditra lainnya, oleh sebab itu tidak heran seandainya banyak terdapat istilah yang sama akan tetapi digunakan pada waditra berbeda, seperti istilah yang biasa digunakan dalam aktifitas ngagesek sekurang kurangnya biasa menggunakan istilah: kerecek, getet, cacag, dan golosor. Sedangkan istilah yang biasa digunakan dalam aktifitas nengkep sekurang kurangnya biasa menggunakan istilah: gedag, kosod, besot, jawil, betrik, lelol, torolok, sorodot, paut, gerentes, keleter, pacok, bintih dan yang lainnya.

Dari sekian banyak istilah tersebut, terdapat istilah-istilah yang hanya dimiliki dan digunakan dalam rebab Sunda yang menuntut kerja keras interpretan menafsirkan bagaimana istilah-istilah tersebut dapat merepresentasikan situasi dan keadaannya. Hal tersebut dijelaskan Chaer dengan mengutif pendapat Edwar Safir dalam bukunya Language Introduction to the Study of Speech (2009:15), yang menyebutkan, bahwa: "...kata mewakili suatu konsep yang saling berhubungan sedemikian rupa dan membentuk kesatuan psikologis."

Berkenaan dengan hal tersebut, Alwasilah (2011:167) dengan tegas menyebutkan bahwa: makna itu ada dibalik kata. Bahkan pada bagian tulisan sebelumnya, Alwasilah (2011:165) juga menegaskan: bahwasannya makna bukanlah berwujud dalam sesuatu, melainkan ada dalam pikiran si pemakai simbol, yaitu si penutur dan si penanggap tutur.

Dalam hubungan musik dan linguistik termasuk istilah berupa kata di dalamnya, selalu menjadi 
bahasan yang menarik, karena diyakini terkandung banyak makna didalamnya, seperti disebutkan Chaer (2009:13) yang menyebutkan, bahwa:

Aristoteles (384 - 322 SM) seorang sarjana bangsa Yunani sudah menggunakan istilah makna, yaitu ketika dia mendefinisikan kata. Menurut Aristoteles kata adalah satuan terkecil yang mengandung makna. Malah dijelakan juga bahwa kata itu memiliki dua macam makna, yaitu (1) makna yang hadir dari kata itu sendiri secara otonom, dan (2) makna yang hadir sebagai akibat terjadinya proses gramatika (Ullman 1977: 3). Makna (1) barangkali bias kita bandingkan sekarang dengan yang disebut makna leksikal, sedangkan makna (2) barangkali kita bias bandingkan dengan yang disebut makna gramatikal.

Sekaitan dengan hal tersebut, maka istilah-istilah yang diterapkan dalam rebab sunda diyakini mengandung makna-makna tertentu di luar bahasa yang masih menuntut penafsiran pemainnya, agar konstruksi pesan-pesan yang terkandung didalamnya, dapat direpresentasikan. Dengan begitu maka diharapkan seorang pemain rebab, memiliki kompetensi dalam mengiterpretasi sekaligus mengimplementasikannya ke dalam kesan-kesan musikal. Berdasarkan itu pula, untuk mengung- kap lebih jauh, maka penulis menganggap perlu untuk dilakukan kajian secara lebih komprehensif.

Berdasarkan uraian di atas, pada akhirnya penulis mencoba mengidentifikasi beberapa permasalahan, yang disusun sebagai berikut: (1) Konstruksi makna apa saja yang melatari terciptanya istilah-istilah dalam garap rebab Sunda?; dan (2) Bagaimana korelasi antara istilahistilah yang dibangun dengan bentuk musikalitas rebab Sunda?

\section{Metode}

Paparan pada tulisan ini merupakan jenis penelitian kualitatif, yang dinyatakan dalam bentuk katakata, narasi, uraian, dan berbagai penjelasan berupa pemahaman lainnya. Secara konkret data yang dikumpulkan terdiri atas rekaman hasil-hasil wawancara kepada para informan. Data dikumpulkan melalui observasi dan dokumen-dokumen lain yang dianggap perlu. Untuk memperoleh data di atas, penelitian ini menggunakan dua jenis sumber data, yaitu sumber data primer dan sumber data sekunder. Sumber data primer didapat dari para informan, sedangkan sumber data sekunder didapat dari berbagai pembicaraan yang sudah dilakukan sebelumnya, 
termasuk literatur-literatur yang dipandang relevan dengan objek penelitian untuk mengupas permasalahan penelitian, terutama literatur yang berkaitan dengan klasifikasi, deskripsi, analisis eksistensi, dan konsistensi berkaitan dengan seni karawitan sunda, khususnya rebab Sunda.

Dalam penjelasan mengenai teknik pengumpulan data, perlu dijelaskan bahwa dalam penelitian kualitatif akan digunakan teknik pengumpulan data yang utama, yaitu observasi partisipasi, wawancara mendalam, studi dokumentasi, dan gabungan dari ketiganya (triangulasi). Dalam penelitian ini, metode dipahami karena berkaitan dengan teknik-teknik pelaksanaan penelitian seperti cara dan teknik pengumpulan data, identifikasi, klasifikasi, reduksi data, dan analisis.

Fokus utama dalam penelitian ini dilakukan karena obyek maupun subyek kajian, tidak bisa dipisahkan dari keterkaitannya dengan dimensi lain, termasuk keterkaitannya dengan pranata, situasi, kehidupan, dan komunitas sosial-budayanya. Oleh karena itu, dalam penerapannya prinsip teori digunakan sebagai upaya mendekati sasaran dan tujuan, tentang obyek beserta subyek yang diteliti.

Dalam pengertian yang lebih luas, menurut Kutha Ratna, metode dianggap sebagai cara-cara, strategi untuk memahami realitas, langkahlangkah sistematis untuk memecahkan rangkaian sebab akibat berikutnya (2010:84). Pada bagian lain tulisannya, Kutha Ratna menyebutkan, bahwa: pada tingkat tertentu metode kualitatif memiliki persamaan dengan interpretasi (verstehen), analisis isi, alamiah, naturalistik, studi kasus, etnografi, etnometodelogi, dan fenomenologi (2010: 85). Meskipun demikian istilah yang paling umum adalah kualitatif.

Metode kualitatif dijelaskan oleh Sugiyono dalam bukunya Metode Penelitian Kuantitatif Kualitatif dan $R \& D$ (2011:8), sebagai berikut:

Metode kualitatif sering disebut metode penelitian naturalistik karena penelitiannya dilakukan pada kondisi yang alamiah (natural setting); disebut juga sebagai metode etnografi, karena pada awalnya metode ini lebih banyak digunakan untuk penelitian bidang antropologi budaya; disebut sebagai metode kualitatif karena data yang terkumpul dan analisisnya lebih bersifat kualitatif. 
Hasil analisis data disajikan secara informal, secara deskriptif yaitu melalui kata-kata, kalimat, dan bentuk-bentuk narasi yang lain. Penyajian secara formal, melalui statistik, diagram, dan tabel hanya bersifat sebagai pelengkap.

Untuk mengungkap masalah dengan tetap mempertahankan hakikat nilai dengan memberikan perhatian pada data, dengan memanfaatkan cara-cara penafsiran yang akan disajikan secara deskriptif, maka metode kualitatif sangat cocok digunakan dalam kajian tulisan ini. Dengan alasan tersebut diharapkan kajian kualitatif dapat mengupas secara sistemik untuk mendapatkan informasi yang akurat, menyeluruh, dan substansial sebagai bahan kajian dari tulisan ini.

\section{Pembahasan}

Seni karawitan termasuk peristiwa beserta pelaku dalam kreativitasnya mencerminkan upaya penyimbolan. Demikian halnya dengan cara kerja kesenian sebagai suatu bentuk simbol menjadi lebih jelas dengan membedakan cara-cara kesenian tersebut menyampaikan makna. Oleh sebab itu upaya penyimbolan dalam bentuk istilah-istilah yang diterapkan dalam rebab sunda, diklasifikasikan menjadi dua kategori.

\section{Kategori Musikal}

Pada kategori ini, istilahistilah pada rebab sunda menggunakan kata atau bentuk ujaran disesuaikan dengan teknik memainkannya, baik ujaran-ujaran yang dihasilkan melalui peniruan bunyi maupun peniruan bentuk visual penjariannya. Oleh karena itu, pada kategori ini memiliki keragaman istilah dibanding kategori yang satunya.

Secara teknis keragaman istilah tersebut kerap digunakan dalam mencirikan simbol bunyi rebab Sunda ke dalam bentuk kata atau bahasa yang bisa dicerna secara leksikal. Pada kategori ini interpretasi tidak begitu berpengaruh, sebab orientasi istilah didasarkan hanya untuk memenuhi serta mewakili situasi tertentu. Oleh sebab itu istilah yang digunakannya pun lebih berkenaan dengan situasi faktual yang bisa merepresentasikan bentuk pekerjaannya, atau secara spesifik, dalam teknik mempelajari rebab dikenal dengan istilah tengkepan dan kesetan. 
Keragaman istilah yang terdapat pada kategori ini, berasal dari berbagai unsur, ada dari personifikasi alam, bentuk fisik, bentuk benda, bahkan bisa berupa tindakan atau perilaku seseorang dan sebagainya, yang konsep pemaknaannya bersifat denotatif ${ }^{1}$ berupa simbolsimbol yang sudah terikat dengan konsep kulturalnya, sehingga konstruksi pesan hanya merepresentasikan pemikiran masyarakat di mana simbol tersebut diciptakan. Simbol berupa Istilah-istilah pada kategori ini, diklasifikasikan sebagai berikut:

\section{a. Gedag}

Dalam kamus bahasa Sunda gedag berarti oyag atau bergerak. Ini mengibaratkan pohon, sedang terhembus angin sehingga berakibat batang pohon, tangkai, dan daun bergerak perlahan sehingga terlihat bergerak-gerak (gedag=endag, bahasa Sunda). Eutik Muchtar berpendapat, gedag bisa dicirikan secara fisik ketika rebab dimainkan terlihat "oyag" karena terjadi tindakan aktifitas jari kiri memainkan dua nada bergantian (wawancara Maret 1990). Hubungannya dengan bunyi rebab, terdengar suara melodi dasar (jari primer) mendapat sentuhan nada lain yang frekuensi nadanya lebih tinggi dari nada pokok di bawahnya (jari secounder) sehingga terdengar menjadi dua suara bergerak bergantian.

b. Kosod

Kosod atau ngosod bunyi yang dihasilkannya hampir sama dengan gedag, pembedanya terletak pada tindakan jari, gedag menggunakan dua jari dan dua nada, kosod menggunakan satu jari dua nada. Kosod/Ngosod dalam makna bahasa Sunda bergerak tapi tidak pindah tempat. Secara teknik memainkan rebab kosod satu jari menghasilkan dua nada, satu nada pokok, satunya lagi nada yang dihasilkan dari jari yang ada dibawahnya sehingga menghasilkan nada sedikit lebih tinggi frekuensinya dari nada pokok.

\section{c. Betrik}

Teknik yang dilakukan dalam melakukan betrik biasanya oleh jari kelingking pada saat akhir melodi, yang berfungsi menutup nada tersebut supaya mati. Teknik ini dilakukan agar nada sebelumnya tidak mengganggu nada yang akan dimainkan. Dalam memainkan gamelan biasa disebut nengkep. 
d. Jawil

Istilah jawil diterapkan pada teknik penjarian rebab sunda dengan maksud untuk meraih nada tertentu dibawah nada pokok dengan teknik pengambilan nada yang biasa dilakukan dengan menggunakan jari kelingking. Berbeda dengan pendapat Soepandi seperti yang terdapat pada Kamus Istilah Karawitan Sunda (1985: 95) yang menyebutkan bahwa jawil merupakan nada-nada yang terletak di antara nada panelu dan nada loloran dalam surupan saléndro 10 nada. Terdapat juga pendapat lainnya, seperti yang tertulis pada Kamus Basa Sunda (2009:285) yang menyebutkan istilah jawil atau dijawil yaitu: ditoel $k u$ curuk bari rada dikait (disentuh menggunakan telunjuk sambil agak dikait).

\section{e. Besot}

Menurut Soepandi dalam Kamus Istilah Karawitan Sunda (1985:40), Besot atau besut adalah cara mengalunan suara dalam membunyikan rebab. Teknik memainkan rebab dalam motif besot, dilakukan dengan cara menarik jari yang menempel pada satu nada pokok tertentu ke atas atau ke bawahnya, sehingga menghasilkan jalinan nada yang diperoleh melalui nada-nada terdekat dari nada pokoknya.

\section{f. Getet}

Istilah getet Menurut Soepandi (1985: 77) gesekan rebab, satu gesek satu nada. Istilah getet diterapkan dengan cara memadukan teknik kesetan dengan tengkepan pada satu nada dan periode tertentu yang dilakukan secepat dan sesingkat mungkin, sehingga bunyi yang dihasilkan seakan terpatah-patah.

\section{g. Torolok}

Istilah torolok atau norolok merupakan istilah tersendiri yang dihasilkan dari tiruan dari kesan visual pergerakan penjarian rebab sunda, ketika menggambarkan teknik penjarian dalam perpindahan 3 atau 4 nada baik turun ataupun naik dalam posisi dan periode tertentu secara bergantian dan berurutan.

\section{h. Sorodot}

Secara teknik antara penjarian sorodot dengan golosor dalam memainkan rebab sunda hampir sama. Diterapkan ketika menyambungkan dari satu nada ke nada lainnya, sehingga terjadi perpindahan nada atau posisi tertentu. Akan tetapi pada teknik sorodot, dilaku- 
kan dalam tempo yang agak cepat, serta perpindahannya bisa ke nada di atasnya ataupun ke nada di bawahnya.

i. Paut

Prinsip dasar paut adalah menarik, "maut nyereka Congona" artinya narik lidi. Teknik paut dalam memainkan rebab yaitu "maut/paut" (konotatif) dari menggeser jari yang memainkan nada, dari atas ke bawah atau sebalikna, biasanya pergeseran jari yang memainkan nada itu hanya satu atau dua nada.

\section{j. Ligar}

Ligar dalam memainkan rebab yakni menggesek rebab dengan dua kawatnya tanpa ditengkep dengan gesekan panjang (golosor). Teknik ligar biasa digunakan pada waktu memainkan nada 1 (da) rendah, yang sekaligus pula berfungsi untuk mengevaluasi laras nada dasar (tonika), barangkali dalam waktu perjalanan memainkan rebab terjadi perubahan rentang kawat (narikan atau ngendoran) yang diakibatkan oleh suhu ruangan atau kualitas kawatnya itu sendiri.

\section{k. Dengdo}

Menurut Soepandi (1988: 57) dengdo adalah bunyi rebab sunda yang dihasilkan dengan cara jari manis menempel pada kawat serta kelingking digetarkan hingga menimbulkan ombak suara. Istilah tersebut lebih berhubungan dengan teknik dalam memainkan rebab sunda, sehingga tidak digunakan pada waditra karawitan lainnya. Menurut Soepandi (1988: 57) dengdo adalah bunyi rebab sunda yang dihasilkan dengan cara jari manis menempel pada kawat serta kelingking digetarkan hingga menimbulkan ombak suara. Istilah tersebut lebih berhubungan dengan teknik dalam memainkan rebab sunda, sehingga tidak digunakan pada waditra karawitan lainnya. Secara leksikal, pengertian dari istilah tersebut tidak terdapat dalam kamus Basa Sunda dan kosakata dari istilah tersebut tidak pernah digunakan oleh masyarakat biasa, bahkan terasa asing di telinga masyarakat Sunda.

\section{Bintih}

Istilah bintih biasanya digunakan dalam kegiatan sabung ayam, seperti disebutkan dalam kamus Basa Sunda (2006: 95) dibasakeun kahayam nu macok musuhna bari luncat bari ngagunakeun siihna. (digunakan pada ayam yang mematuk musuhnya sambil loncat sambil menggunakan tajinya). Peminjaman 
istilah tersebut berkenaan dengan visualisasi penjarian rebab sunda yang dilakukan dengan seperti halnya ketika ayam jantan menghujamkan tajinya. Secara teknik, bintih dalam penjarian rebab sunda dilakukan dengan menggunakan patukan salah satu jari di bawahnya, sementara jari di atasnya harus dalam keadaan menempel (nengkep) pada nada tertentu. Itu semua harus dilakukan dengan cepat, disertai dengan tekanan kesetan pendek secara berulang sesuai kebutuhan. Sehingga melalui perpaduan patukan dengan tekanan kesetan tersebut dapat menghasilkan hentakan-hentakan nada.

\section{m. Kerecek}

Istilah kerecek merupakan istilah yang dihasilkan dari tiruan bunyi kesan visual penjarian rebab sunda, berupa pengulangan nadanada yang sama yang dilakukan bergantian secara konstan.

\section{n. golosor}

Secara harfiah istilah golosor merupakan perpindahan dari satu tempat yang lebih tinggi ke tempat yang lebih rendah. Begitupun pada waditra rebab, istilah tersebut diterapkan pada perpindahan nada ke nada yang lebih rendah yang dilakukan secara pelan dan hati-hati, sehingga perpindahan nadanya terasa mengalir.

\section{Kategori Makna Bahasa}

Pada kategori ini, konsep pemaknaan berupa istilah-istilah yang digunakan menjadi aspek penting untuk mengetahui konstruksi pesan yang terkandung di dalamnya. Konstruksi makna yang terbentuk pada perspektif ini kemudian menjadi dasar terbentuknya ideologis tertentu. Menurut Sarwiji (2008:71) yang dimaksud dengan makna konstruksi (construction meaning) adalah makna yang terdapat dalam konstruksi kebahasaan. Jadi, makna konstruksi dapat diartikan sebagai makna yang berhubungan dengan kalimat atau kelompok kata yang ada di dalam sebuah kata dalam kajian kebahasaan.

Pada tataran ini, maknanya lebih bersifat konotatif, oleh sebab itu individu menjadi bagian penting yang dituntut memiliki kemampuan untuk menafsirkan sekaligus merepresentasikan sendiri simbol-simbolnya. Yang menarik pada kategori ini, leksem-leksem ${ }^{2}$ yang digunakan lebih bermakna referensial, meskipun tidak ada referensi atau acuan 
seperti yang biasa mensyaratkannya. Istilah-istilah dalam rebab Sunda dalam kategori di atas, antara lain:

\section{a. Gerentes}

Kata gerentes dalam bahasa Sunda memiliki kandungan makna emotif dalam penggunaannya. Disengaja atau tidak, ada maksud tersembunyi untuk membangun relasi yang menghubungkan teks pada konteksnya yang ingin disampaikan dengan cara halus dan tersembunyi.

Dalam keseharian istilah gerentes bermakna referensial, sebab harus terdapat leksem lainnya sebagai referensinya, sehingga bentuk ujarannya menjadi gerentes hate.

Pada praksisnya, gerentes bukan sekedar mengutamakan teknik, akan tetapi harus menjangkau wilayah yang lebih luas melebihi tekniknya, sehingga sangat dibutuhkan keterlibatan emosi sebagai refleksi. Kualitas teknik gerentes seorang pengrebab dapat pula mencirikan identitas pengrebab tersebut. Dengan kata lain, salah satu alat ukur hasil bunyi seorang pengrebab bisa diukur dari bunyi rebaban ketika seseorang itu meminkan teknik gerentes. b. Meujit

Istilah meujit yang digunakan dalam rebab sunda, kedalaman istilahnya hampir tidak bisa diukur sehingga memunculkan ambiguity. Istilah meujit asal katanya dari peujit yang dalam bahasa Sunda pengertiannya sama dengan usus yaitu salah satu organ pencernaan yang terdapat di dalam perut.

Fonem "p" pada kata peujit setelah diganti dengan fonem $M$ (nasal) pengucapannya berobah menjadi meujit, sehingga fonem " $\mathrm{p}$ " tersebut memiliki fungsi merubah makna, dengan begitu maka pengertiannya pun turut berubah menjadi " aya dijero peujit' atau berada di dalam usus.

Istilah meujit digunakan bukan bermakna konseptual, akan tetapi lebih bersifat kiasan, sehingga meujit yang pengertiannya sama dengan masuk dan berada di dalam peujit atau usus, lebih bermakna hapal dan mengerti serta mampu mengaplikasikan dengan sangat mendalam.

c. Renghapan

Renghapan asal katanya dari renghap yang pengertiannya sama dengan nafas, yaitu menghirup 
udara untuk memenuhi kebutuhan oksigen mahluk hidup, sekaligus sebagai penanda kehidupannya. Konstruksi makna dalam istilah renghapan digunakan dalam rebab sunda, ingin menunjukan pesanpesan penting yang sesuai makna konseptualnya.

Istilah renghapan menunjukan lebih dari satu atau beberapa renghap, sebab renghap sebagai tanda linguistik memiliki 2 unsur, yaitu unsur makna "renghap" dan unsur bunyi (r-e-n-g-h-a-p). Unsur makna "renghap" secara referensial bisa digambarkan bentuknya sebagai upaya menghirup udara dikala bernafas. Oleh sebab itu pengertiannya sangat ditentukan situasi dan kondisi antara yang ditandai dengan yang menandai yang secara referensial masih membutuhkan alat bantu yaitu semantik leksikal, sehingga pemaknaan akan menjadi berbeda seandainya disandingkan dengan leksem lain sebagai pembatasnya, sebagai contoh dengan menyandingkannya dengan istilah ranjug, menjadi renghap ranjug maka keluasan makna yang dikandungnya pun ikut dibatasi.

Secara teknis selama leksemnya tidak dibatasi istilah renghapan, memiliki varian tidak terbatas, karena penggambaran makna dari unsur yang ditandainya sebagai sesuatu di luar bahasa atau ekstralingual, menyebabkan referen sama sekali sulit dikenali. Pada bagian ini maka mutlak diperlukan kemampuan dari seorang pemain rebab untuk menafsirkannya ke dalam bentuk representasi estetik.

d. Lelol

Istilah lelol memiliki keunikan tersendiri, sebab bisa ditelisik menggunakan beberapa pendekatan berbeda, antara lain: 1) mencermati antara musikalitas dengan istilah yang digunakannya, terdapat kesesuaian ritmis sehingga memenuhi unsurunsur yang dapat dikategorikan onomatope, sebab kata lelol ketika dilafalkanakan tercipta dua pengulangan suku kata secara bergantian antara "lel" dan "lol" dalam tingkatan berbeda, yang secara musikal mirip dengan bunyi yang dihasilkannya; 2) Dalam kamus bahasa Sunda, lelol atau kata kerja nya jadi balelol: "dibasakeun ka budak olo leho anu dina ngalisankeun kekecapan $r, l, d$, $b$, $t$, lantaran masih pahili (pego, pireu, cadel $)=($ diibaratkan kepada anak kecil yang melafalkan vokal $r, 1$, $\mathrm{d}, \mathrm{b}, \mathrm{t}$ masih belum fasih, sehingga bias tertukar). Lelol dalam konteks 
ini bermakna proses pencapaian kompetensi yang belum sempurna karena belum cukup umur menuju ke arah pendewasaan.

Melengkapi bahasan tentang lelol, Suryaman (wawancara, 01 Nopember 2016) memiliki pendapat berbeda, menurut penuturannya: istilah lelol berawal dari balelol, yaitu ucapan dari seseorang menjelang sakaratul maut, biasanya berisi amanat, atau nasehat terakhir seseorang yang diucapkan dengan tidak sempurna dan tidak jelas, tapi memiliki kesan mendalam, karena diucapkan di saat akhir hayatnya orang tersebut menyampaikan pesan terakhir kepada keluarganya.

Keragaman pendapat yang diperoleh dari beberapa sumber termasuk beberapa referensinya, merupakan sesuatu yang tidak perlu dipertentangkan. Hal ini disebutkan Chaer (2009:10) yang menyebutkan bahwa: ...perbedaan pengertian dari ujaran itu bukan tergantung dari makna kata-kata yang bersangkutan melainkan dari maksud si pengujar.

e. Renghik

Istilah renghik dalam basa sunda biasa diterapkan pada situasi dan kondisi, pada saat seseorang sedang larut dalam suasana kese- dihan. Dalam peristiwa berbeda istilah tersebut juga biasa diistilahkan pada anak kecil yang sedang rewel karena menginginkan sesuatu karena belum dipenuhi keinginannya. Meskipun peristiwanya berbeda, akan tetapi memiliki kesamaan suasana yaitu sama-sama dalam keadaan sedih. Kondisi ini melatari sifat dan karakter dari waditra rebab sunda pada umumnya. Hal ini dijelaskan Suryaman (wawancara, Maret 2015) yang menyebutkan bahwa: penggambaran rebab seperti yang di amanatkan oleh Nandang Barmaya, harus sampai menyayat hati dan menyentuh jiwa. Oleh karena itu, rebab selalu disimbolkan dengan sosok perempuan lengkap dengan kehalusan, kepekaan, ketelitian dan keibuannya.

Istilah renghik yang disebarkan Barmaya merupakan gambaran dari suasana kesedihan yang diaplikasikan pada rebab sunda menggunakan teknik tekanan kesetan secara berulang pada nada-nada tinggi, serta biasanya menggunakan laras sorog. Jenis bunyi rebab renghik juga sering disebut lengis.

\section{Penutup}

Merujuk pada substansi kajian yang dilakukan, sebagaimana 
diuraikan pada bagian rumusan masalah dan pembahasan, maka dapat ditarik kesimpulan sebagai suatu sintesa, yakni: (1) Pada perspektif ideologis tertentu, konsep kultural menjadi ranah pemikiran masyarakat di mana simbol tersebut diciptakan. Kode kultural yang menjadi salah satu faktor konstruksi makna dalam sebuah simbol atau istilah dalam aspek linguistic dengan menerapkan ujaran-ujaran yang coba dimanfaatkan dalam rebab Sunda semata-mata demi musik itu sendiri, dengan memberikan keleluasaan kepada individu untuk merepresentasikannya; dan (2) korelasi antara istilah dengan praksisnya, tercipta relasi yang menghubungkan antara istilah dengan tekniknya, sehingga beberapa di antaranya terdapat istilah berupa kiasan-kiasan serta onomatope ${ }^{3}$, (menggantikan bunyi aslinya) sebab leksem-leksemnya memiliki kekuatan ritmis yang dihasilkan melalui representasi musikalnya.

\section{CATATAN AKHIR}

1 Chaer mengartikan makna denotatif adalah makna asli, makna asal, atau makna sebenarnya yang dimiliki oleh sebuah leksem. Makna denotatif mengacu makna asli atau makna sebenarnya dari sebuah kata atau leksem (1994: 292).

2 Menurut Chaer (2009: 8) menyebutkan bahwa: Leksem adalah istilah yang lazim digunakan dalam studi semantic untuk menyebut satuan bahasa bermakna. Istilah leksemini kurang lebih dapat dipadankan dengan istilah kata yang lazim digunakan dalam studi morfologi dan sintaksis, dan yang lazim didefinisikan sebagai satuan gramatikal bebas terkecil.

3 Onomatope merupakan istilah dalam bahasa Yunani, yaitu pembuatan nama-nama yang meniru bunyi-bunyi yang ditandainya. Menurut Suhardi (2013:33) menyebutkan bahwa: Pada mulanya, kata-kata adalah tiruan barang-barang yang dinamai onomatope, yaitu inti pembendaharaan kata.

\section{DAFTAR PUSTAKA}

Abdul Chaer, 2009. Pengantar Semantik Bahasa Indonesia, Jakarta: Rineka Cipta.

\section{Linguistik} Umum. Jakarta: Rineka Cipta.

A. Chaedar Alwasilah, 2011. Linguistik Suatu Pengantar. Bandung: Angkasa.

Atik Soepandi, 1975. DasarDasar Teori Karawitan, Bandung: Lembaga Kesenian Seri A/I.

1988/1989. Kamus Istilah Karawitan Sunda, Bandung:CV. Satu Nusa.

Jakob Sumardjo, 2000.Filsafat Seni, Bandung: Institut Teknologi Bandung.

Nyoman Kutha Ratna. 2010. Metodologi Penelitian: Kajian Budaya dan Ilmu 
Sosial Humaniora Pada Umumnya, Yogyakarta: PustakaPelajar.

2011. Teori, Metode, dan Teknik Penelitian Sastra, Yogyakarta: Pustaka Pelajar.

R.A. Danadibrata, 2006. Kamus Basa Sunda, Bandung: PT. Kiblat Buku Utama

Suhardi, 2013. Pengantar Linguistik Umum, Yogyakarta: Ar-Ruzz Media.

Sugiyono. 2007. Metode Penelitian Kuantitatif dan Kualitatif dan $R \& D$, Bandung: Alfabeta

Suwandi, Sarwiji. 2008. Semantik Pengantar Kajian Makna. Yogyakarta: Media Perkasa.

Towa P Hamakonda. 2000. Pengantar Klasifikasi, PT BPK Gunung Mulia, Jakarta.

R. Satjadibrata. 2005. Kamus Basa Sunda, Bandung: Kiblat Buku Utama.

\section{DAFTAR NARA SUMBER:}

Eutik Muchtar, Tokoh Rebab Sunda, Kreator lagu kiliningan, Pelatih kepesindenan
Maman Suryaman, S.Sen, Guru rebab SMK 10, murid rebab Nandang Barmaya di Kokar Bandung.

Yoyo Risyaman, S.Sen, Pensiunan Budpar Provinsi Jawa Barat, pernah menjadi guru di SMKI, murid rebab Eutik Muchtar.

Atang Warsita,S.Sen, Pensiunan Budpar Provinsi Jawa Barat, pernah menjadi guru di SMKI, Alok, Kreator lagu wanda anyar.

Pandi Upandi,S.Kar, M.Sn, pensiunan Dosen ISBI. 